\title{
PERUBAHAN HUKUM DALAM PANDANGAN IBNU QAYYIM
}

\author{
Abdi Wijaya \\ Fakultas Syariah dan Hukum Universitas Islam Negeri (UIN) Alauddin Makassar
}

\begin{abstract}
:
The transformation of Islamic law is a necessity that must occur in response to contemporary problems faced by society. The transformation of Islamic law is closely linked to various factors within the framework of Islamic law. These factors are mixed and used as the theory of Ibn Qayyim to become an "icon". That is the factor of the times, places, situations of intention and custom.

Keyword:

Islamic Law, transformation.

\section{Abstrak:}

Transformasi hukum Islam adalah sebuah keniscayaan yang harus terjadi dalam merespon persoalan-persoalan kontemporer yang dihadapai oleh masyarakat. Transformasi hukum Islam tersebut sangat terkait dengan berbagai faktor yang berada dalam bingkai hukum Islam. Faktor-faktor tersebut diramu dan dijadikan sebagai teori Ibnu Qayyim menjadi sebuah "icon". Yaitu faktor zaman, tempat, situasi niat dan adat.
\end{abstract}

\section{Keyword:}

Hukum Islam, transformasi.

\section{A. PENDAHULUAN}

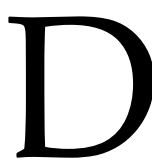

alam hukum Islam, ada dua kategori hukum Islam, yaitu hukum Islam yang

bersifat tetap dan yang bersifat elastis. Hukum Islam yang bersifat tetap tersebut, tidak mengalami perubahan sepanjang masa. Kategori yang bersifat tetap adalah biasanya hukum-hukum yang berkaitan dengan ibadah mahdah. Sedangkan hukum yang bersifat elastis biasanya mengalami tranformasi seiring berubahnya zaman, kondisi dan kebiasaan-kebiasaan. Jenis hukum tersebut biasanya yang berhubungan dengan masalah-masalah muamalah.

Dua jenis kategori hukum yang disebut di atas, Hukum yang bersifat elastis yang banyak mendapat porsi jikia dibandingan dengan hukum yang bersifat tetap. 
Bagi hukum yang bersifat elastis, maka penjabaran dan implementasi pronsipprinsip perlu dilakukan, sehingga hukum Islam tidak menjadi stagnan dan senantiasa sesuai dengan perubahan masyarakat.

Terkat hal tersebut yang dikemukakan di atas, Ibnu Qayyim mengemukakan bahwa transformasi hukum Islam senantiasa beriringan dengan transformasi tradisi. Prinsip ini memberi posisi penting bagi tradisi sebagai pemegang kunci transformasi hukum Islam. Artinya, jika terjadi perubahan tradisi itu akan diikuti oleh perubahan hukum Islam. ${ }^{1}$ Dalam hal ini Ibn Qayyim mengajukan dua kasus transformatif untuk mendukung pokok pikirannya, yaitu:

1. Transformasi hukum adsalah suatu tindakan berdasar makna tradisi, makna urf . secara operasional prinsip ini dapat dicermati pada kasus transformasi penetapan hukum pada suatu tindakan yang didasarkan pada arti tradisi. Penetapan hukum suatu kasus yang berkaitan dengan pemikiran makna suatu ungkapan yang berkaitan dengan pemakaian makna suatu ungkapan harus didasarkan pada makna tradisi dan bukan pada makna leksikal. ${ }^{2}$

2. Transformasi hukum suatu kasus berdasarkan pada prilaku tradisi, Secara operasional prinsip ini dapat dicermati pada kasus transformasi penetapan hukum suatu tindakan dan prilaku yang didasarkan pada prilaku dan tindakan. Penetapan hukum tentang prilaku yang sudah mentradisi harus didasarkan pada rasa keadilan hukum tradisi, selagi panduan syar'i dalam keadaan netral dan vakum. ${ }^{3}$

Jika dikaji secara umum, pemikiran hukum Islam di atas, secara representatif mendukung prinsip tradisi sebagai kunci penyebab transformasi hukum Islam. Secara sosiologis, tradisi atau adat istiadat merupakan bentuk kontrol sosial tertua. Tradisi merupakan seperangkat prosedur yang muncul secara bertahap dari generasi ke generasi lainnya sampai terjadinya keyakinan sosial.4. Oleh karena itu dapat dinyatakan bahwa tradisi merupakan salah satu variabel bagi terjadinya perubahan hukum.

Perubahan hukum sebagai suatu kemestian dalam sistem hukum Islam harus dipahami secara proporsional. Dikatakan demikian karena proporsionalitas perubahan hukum akan menempatkan setiap permasalahan secara tepat dan benar. Hal ini penting karena tanpa proporsionalitas, bisa saja perubahan hukum yang dilakukan akan tercabut dari akarnya.

${ }^{1}$ Mujiono Abdillah, Dialektika Hukum Islam dan Peubahan Sosial: Sebuah Refleksi Sosiologis Atas Pemikiran Ibn Qayyim al-Jauziyyah (Surakarta: Muhammadiyah University Press,. 2003), h. 90.

2 Mujiono Abdillah, Dialektika Hukum Islam dan Peubahan Sosial: Sebuah Refleksi Sosiologis Atas Pemikiran Ibn Qayyim al-Jauziyyah, h. 90.

${ }^{3}$ Mujiono Abdillah, Dialektika Hukum Islam dan Peubahan Sosial: Sebuah Refleksi Sosiologis Atas Pemikiran Ibn Qayyim al-Jauziyyah, h. 90.

${ }^{4}$ Mujiono Abdillah, Dialektika Hukum Islam dan Peubahan Sosial: Sebuah Refleksi Sosiologis Atas Pemikiran Ibn Qayyim al-Jauziyyah, 91. 


\section{B. PEMBAHASAN}

\section{Biografi Ibnu Qayyim}

Ibnu Qayyim bernama lengkap Abu Abdullah Syamsuddin Muhammad bin Abu Bakar bin Ayyub bin Saad al-Dimasyqi al-Jauziyah. Ia dilahirkan pada tahun $691 \mathrm{H}$ bertepatan $1292 \mathrm{M}$ dan wafat pada tahun $751 \mathrm{H}$ beretepatan dengan tahun 1350 M. Ia seorang ahli fikih dan seorang mujtahid Hambali.

Ibn Qayyim belajar pada Ali Shihab an-Nablisi al-Qabir dan kepada ulamaulama lainnya.Gurunya yang paling berpengaruh adalah Inbu Tamiyah. Walaupun demikian ia tidak jarang berbeda pendapat dengan gurunya bila menurutnya sesuatu itu benar dan jelas dalilnya. Ilmu yang ia peroleh diajarkan pula kepada muridnya, seeperti Inbu Katsir, Zainuddin Abu alFariz Abdurrahman, Syamsuddin Muhammad bin Abd.Qahhar al-Nablisi, Ibn al-Hadi dan lain-lainnya. Ibnu Qayyim pernah masuk penjara bersama gurunya,ibnu Taimiyah. Ia dimasukkan ke penjara karena mengharamkan berhaji ke masjid Ibrahim.

Ibnu Qayyim terkenal perpegang teguh dan membela kemurnian Alquran dan hadis. Ia jiuga dikenal sebagai penentang paham sufi yang menurutnya bertentangan dengan Alquran dan hadis, misalnya wihdatul wujud, ittihad maupun hulul. Pahampaham tersebut menurutnya lebih banyak menggunakan akal karena tidak jelas sumber rujukannya. Pendapatnya cukup tegas karena tidak saja bersifat kritis terhadap berbagai aliran tersebut, bahkan juga terjadi perbedaan pendapat dengan ulama fikih mazhab Hambali. ${ }^{5}$

Dalam dunia tulis menulis, ia dikenal sebagai penulis yang produktif, hal tersebut dapat dilihat dengan karya-karyanya, diantaranya yang berkaitan dengan tauhid yaitu; Syifa al-Alil fi masail al Qadha wa al-Qadr, ar-Ruh, dan lain-lainnya. Dalam kitab-kitab fikih karya yang dihasilkan oleh ibnu Qayyim diantaranya I'lam alMuwaqqi'in, Bayan al-Dalil ala Istiqna al-Musabaqat an at-Tahlil dan lain-lain. Selain kitab-kitab yang telah disebutkan sebelumnya, Ibnu Qayyim juga menulis buku tasawwuf dan sejarah, diantara buku-buku tersebut adalah Iddat Sabirin dan alFawaid, akhbar al-Nisa dan Zaad al-Ma-ad dan lain-lain.

\section{Ibnu Qayyim dan Teori Perubahan Hukumnya}

Perubahan hukum dalam pandangan Ibnu Qayyim yaitu perubahan hukum dapat saja terjadi sebagaimana fatwa selalu mengalami perubahan. Perubahan hukum sesungguhnya, bukan saja yang dilakukan oleh Ibnu Qayyim, akan tetapi perubahan hukum telah pernah dilakukan oleh Imam Syafi-i dengan konsep perubahan hukumya yaitu Qaul al-Qadim dan Qaul al-Jadid. Dengan demikian perubahan hukum dalam bentuk fatwa telah menjadi tradisi sejak dulu yang dilakukan oleh para fukaha sampai saat ini. Dan hai ini merupakan tugas yang harus dilakukan oleh para fukaha dan pemikir hukum Islam agar supaya hukum Islam tetap eksis dan mampu mengakomodir segala permasalahan yang selalu dinamis.

\footnotetext{
${ }^{5}$ Abdillah F. Hasan, Tokoh-Tokoh Mashur Dunia Islam (Cet. I; Surabaya; Jawara,n 20040, H. 227.
} 
Dalam bukunya, I'lam al-Muwaqqi'in, Ibnu Qayyim mengemukakan teorinya yaitu; Terjadinya perubahan fatwa dan terjadinya perbedaan hukum disebabakan adanya faktor tempat, situasi, niat dan adat. ${ }^{6}$ Dalam pandangan Ibnu Qayyim bahwa adanya perubahan dan perbedaan hukum pada dasarnya merujuk kepada esensi syariat Islam yang senanatiasa berasaskan kemaslahatan manusia. Syariat tersebut bertujuan mewujudkan suatu keadilan hukum, kemaslahatan, dan kebajikan. Setiap masalah yang yang tidak memenuhi asas keadilan sesungguhnya bertentangan dengan syariat Islam. ${ }^{7}$

Adapun teori perubahan hukum yang diajukan oleh Ibnu Qayyim sebagai berikut;

\section{a. Faktor Zaman}

Terkai dengan faktor ini, Ibnu Qayyim mengemukakan bahwa ketika Nabi Saw melihat kemungkaran di Mekah, kemungkaran tersebut tidak dapat diubahnya, akan tetapi setelah Fathul Makkah dan umat Islam meraih kemenangan, maka segala kemungkaran dapat diubah. ${ }^{8}$, Hal tersebut memberikan indikasi bahwa perubahan hukum sangat dipengaruhi oleh zaman. Mencegah kemungkaran adalah kewajiban umat Islam. Akan tetapi Mekah pada saat itu belum memungkinkan, maka nanti setelah Fathul Makkah umat Islam mampu melakukan perubahan terhadap kemungkaran sehingga kemungkaran tersebut dapat dikendalikan dengan baik.

Pada awal kedatangan Islam, harus diakui bahwa masyarakat Mekah mereka berada pada zaman jahiliyah, kemungkaran dan segala tindak kriminal yang ada pada saat itu sangat tidak meresahkan masyarakat. Dalam kondisi demikian, hukum Islam tidak dapat dipaksakan untuk diterapkan, akan tetapi melalui tahapan dan proses yang panjang. Dengan kata lain dibutuhkan sebuah proses gradual dan dibutuhkan kehati-hatian yang ekstra, sebab jika hukum Islam dipaksakan akan menjadi kontraproduktif dalam mengembangkan misa Islam pada saat itu. Contoh yang bisa digambarkan yaitu proses pengharaman khamar yang tidak secara langsung diharamkan akan tetapi ia secara gradual. ${ }^{9}$

b. Faktor Tempat

Dalam penjelasan tentang tempat, Ibnu Qayim melarang memotong tangan musuh dalam medan perang. Pelarangan tersebut dilakukan dengan alasan bahwa peperangan tersebut terjadi di wilayah musuh. ${ }^{10}$. Hal ini memberikan indikasi bahwa pemberlakuan hukumIslam tidak harus dipaksakan pada wilayah yang lain. Dalam uraian yang lain disebutkan bahwa Nabi Saw pernah mewajibkan zakat fitrah berdasarkan makanan pokok dari penduduk setempat. Nabi Saw mentapkan zakat fitrah berupa satu gantang kurma atau satu gantang gandum atau satu gantang

\footnotetext{
${ }^{6}$ Ibn Qayyim al-Jauziyah, I'lam al Muawaqqiin 'an al-Alamin, Juz III (Bairut: Dar al-Fikr, t.th), h. 14.

${ }^{7}$ Ibn Qayyim al-Jauziyah, I'lam al Muawaqqiin 'an al-Alamin, Juz III, h. 2.

${ }^{8}$ Ibn Qayyim al-Jauziyah, I'lam al Muawaqqiin 'an al-Alamin, Juz III, 16.

${ }^{9}$ Ibn Qayyim al-Jauziyah, I'lam al Muawaqqiin 'an al-Alamin, Juz III, 2.

${ }^{10}$ Ibn Qayyim al-Jauziyah, I'lam al Muawaqqiin 'an al-Alamin, Juz III, h.2.
} 
anggur bagi penduduk kota Madinah. Hal tersebut ditetapkan oleh Nabi Saw berdasarkan bahwa jenis makanan yang telah disebutkan merupakan makanan pokok bagi penduduk Madinah.

Adapun penduduk kota lainnya yang makanan pokoknya selain yang telah disebutkan sebelumnya, maka kewaqjiban penduduk yang ada di kota tersebut untuk mengeluarkan zakatnya berdasarkan makanan pokok yang mereka konsumsi. Seabagaimana jika suatu daerah makanan pokok tersebut berupa jagung atau beras atau buah tin atau yang lainnya berupa biji-bijian, maka kewajiban bagi penduduknya untuk mengeluarkan zakatnya dari jenis makanan utamanya. Demikian halnya jika yang menjadi makanan pokok suatu daerah adalah daging, susu, ikan, maka zakat fitrahnya yang wajib dikeluarkan adalah sesuai dengan makanan pokok tersebut di suatu daerah. ${ }^{11}$

Berdasarkan uraian tersebut di atas, maka menurut Ibnu Qayyim diperbolehkan mengeluarkan zakat fitrah berupa makanan pokok apa saja sesuai apa yang berlaku pada sebuah masyarakat tersebut. Makanan pokok masyarakat Mekkah seperti gandum ketika itu, berbeda dengan makanan pokok bangsa yang lain.

c. Faktor Situasi

Dalam sejarah dikemukakan, Umar bin al-Khattab tidak memberlakukan hukum potong tangan terhadap seorang pencuri pada masa paceklik. ${ }^{12}$ Pernyataan ini dikemukakan Ibnu Qayyim dalam bukunya. Senada dengan hal tersebut, menurut Abbas Mahmud Akkad lebih lanjut menyatakan bahwa tindakan Umar tersebut yang tidak menjatuhkan hukuman terhadap pelaku pencurian tersebut, pada dasarnya tidak meninggalkan nash karena pelaku tersebut melakukannya secara terpaksa sebagai bagian dari tuntutan kelangsungan hidup dan keselamatan dari bencan kelaparan. Dewngan demikian, pelaku pencurian dianggap sebagai orang yang tidak melakukan dosa dengan perbuatannya tersebut. ${ }^{13}$

Perbuatan mencuri adalah perbuatan yang dilarang oleh syariat, akan tetapi perbuatan tersebut dapat ditoleransi ketika jika akan meninggal tanpa makan dan hanya satu-satunya cara untuk dapat bertahan hidup dengan cara ia mencuri hanya sekedar memenuhi makan. Karena perbuatan yang dilakukannya dalam rangka menjaga jiwa yang merupakan salah satu unsur maqasid al-Syari'ah. Demikian halnya dalam kaidah usul disebutka bahwa siuasi emergensi membolehkan yang dilarang yang dibuat ulama sebagai pertimbangan dalam menetapkan hukum.

\section{d. Faktor Niat}

Terkait dengan niat, niat adalah sengaja untuk melakukan sesuatu yang disertai dengan perbuatan. ${ }^{14}$ Terkait perubahan hukum dengan masalah niat, Ibnu Qayyim

\footnotetext{
${ }^{11}$ Ibn Qayyim al-Jauziyah, I'lam al Muawaqqiin 'an al-Alamin, Juz III, 9-10.

${ }^{12}$ Ibn Qayyim al-Jauziyah, I'lam al Muawaqqiin 'an al-Alamin, Juz III, 16.

${ }^{13}$ Abbas Mahmud Akkad, al-Tafkir Faridah Islamiahi, (Kairo: Nahdah Masri, t.th.), 100

${ }^{14}$ Muhammad Ismail al-Kahlani, Subul al-salam min Adillat al-Ahkam (Bairut: Dar- al-Fikr, 1979), h. 26.
} 
mengangkat kasus pada peristiwa ketika suami mengatakan kepada istrinya jika aku mengizinkanmu keluar menuju kamar mandi, maka jatulah talakmu. Oleh karena sesuatu dan lain hal, istrinya membutuhkan kamar mandi tersebut, maka berkatah suaminya "keluarlah". ${ }^{15}$ Oleh sebahagian masyarakat menganggap bahwa jatulah talak bagi si istri hanya dengan kata "keluarlah". Si suami kemudian mempertanyakan hal tersebut kepada seorang mufti. Jawaban mufti menegaskan bahwa talak telah jatuh kepada si istri dengan perkataan "keluarlah" dari si suami. ${ }^{16}$

Uraian di atas, menurut Ibnu Qayyim dianggap suatu hal yang bodoh karena kata "keluar" bukan dimaksudkan oleh suami sebagai izin. Tindakan mufti yang menceraikan suami dari istrinya tersebut adalah hal yang tidak diizinkan oleh Allah Swt. dan Nabi Swa, demikian juga tidak dibolehkan oleh para imam. ${ }^{17}$

Kasus yang dihadapi diatas oleh Ibnu Qayyim merupakan gambaran hukum bahwa ketetapan hukum tidak boleh mengindahkan niat dari pelaku hukum. Hal tersebut menunjukkan bahwa posisi niat dalam sistem hukum Islam menempati kedudukan penting yang mampu merubah suatu hukum yang telah ditetapkan.

e. Faktor Adat

Menurut Ibnu Qayyim faktor adat sama halnya dengan urf yang teramsuk salah satu faktor dapat merubah hukum. Dicontohkan dengan orang yang bersumpah untuk tidak mengendarai "dabbah" Dimana di daerah tersebut kata "dabbah" sesuai dengan urf/adat yang berlaku diartikan keledai. Oleh karena itu, sumpahnya hanya berlaku untuk mengendarai hewan yang bernama keledai. Adapun jika orang tersebut mengendarai kuda atau onta, maka tidak ada konsekuensi hukum baginya. ${ }^{18}$ Demikian juga sebaliknya, jika yang dimaksud: "dabbah" sesuai dengan adat/urf pada daerah lainnya adalah kuda, maka sumpahnya tersebut hanya berlaku untuk hewan kendaraan yang bernama kuda. Hal tersebut memberi indikasi bahwa perubahan hukum selalu memperimbangkan adat/urf suatu daerah.

Bahkan lebih jauh menurut Ibnu Qayyim, jika sesorang mendatangimu dari daerah yang berlainan denganmu meminta keputusan hukum, maka tanyakanlah tentang adat/urf yang berlaku di daerahnya dab berilah keputusan hukum berdasarkan adat/urf yang berlaku di daerahnya, bukan berdasarkan adat/urf yang berlaku di daerahmu. ${ }^{19}$. Demikian juga halnya seorang mufti tidak dibolehkan mengeluarkan fatwa berdasarkan adat/urf yang terjadi pada masa yang lalu. ${ }^{20}$ Dengan uraian teori perubahan hukum yang terkait dengan adat tersebut, maka seorang penegak hukum hendaknya selalu mempertimbangkan faktor-faktor

\footnotetext{
${ }^{15}$ Ibn Qayyim al-Jauziyah, I'lam al Muawaqqiin 'an al-Alamin, Juz III, h. 44.

${ }^{16}$ Ibn Qayyim al-Jauziyah, I'lam al Muawaqqiin 'an al-Alamin, Juz III, 44.

${ }^{17}$ Ibn Qayyim al-Jauziyah, I'lam al Muawaqqiin 'an al-Alamin, Juz III, h. 44.

${ }^{18}$ Ibn Qayyim al-Jauziyah, I'lam al Muawaqqiin 'an al-Alamin, Juz III, h. 43.

${ }^{19}$ Muhammah Said al-Asmawi, Jauhar al Islam (Cet. III; Kairo: Sina, 1993), h. 29.

${ }^{20}$ Nadiyah Syarif al-Umri, Ijtihad fi al-Islami: Usuluhu, aahkamuhu, afatuhu (Cet.I; Bairut; Muassasah al-Risalah, 2001), h. 246.
} 
yang mempengeruhi penetapan suatu hukum. Hal ini juga berarti bahwa seorang mufti, pembuat dan penegak hukum harus berwawasan luas dan mengetahui aspekaspek yang berpengarug dalam penetapan hukum. Dalam konteks tersebut dapat dipahami bahwa perubahan hukum sebagaimana yang dikemukakan oleh Ibnu Qayyim, pada dasaranya berbasis pada realitaskehidupan masyarakat yang senantiasa berubah-ubah. Setiap masa- dari generasi ke generasi tidak sama dengna masa yang dihadapi oleh generasi sebelum dan setelahnya, sehingga perubahan hukum tidak dapat dihindarkan. Di sisi lain, perubahan hukum sejalan dengna misi ajaran Islam yang senantiasa relevan dengan situasi dan kondisi masyrakat. Esensi perubahan hukum Islam, pada dasarnya inheren dengan permaslahan kontemporer yang dihadapi oleh masyarakat. Persoalan yang dihadapi masyarakat mengalami perbedaan sesuai dengan perbedaan zaman, tempat kondisi yang berbeda. Dengan demikian, diperlukan suatu usaha yang maksimal dalam rangka meyelaraskan realitas kehidupan dengan hukum Islam yang bersumber dari nash Alquran dan hadis. Selain berlandaskan kedua sumber tersebut, pintu ijtihad ${ }^{21}$ senantiasa dibuka untuk mengakomodir permaslah-permasalan kontemporer yang selalu dinamais dan membutuh solusi.

Kemajuan ilmu pengetahuan dan teknologi telah melahirkan sejumlah permaslahan-permasalahan yang tidak pernah terjadi pada masa Nabi, Sahabat dan tabi'in, sehingga perubahan hukum pun mutlak terjadi. Permasalahan-permaslahan tersebut perlu direspon dan diberikan solusi. Ibnu Qayyim hadir dengan menawarkan bagunan epistimologinya yaitu bahwa setiap permaslahan hukum harus dibicarakan atau ditetapkan berdasarkan konteksnya. Maksudnya bahwa perbedaan hukum dan perubahan hukum Islam adalah masalah yang logis dan tidak perlu diperdebatkan. Ia beralasan bahwa jika perubahan hukum harus berbasis pada realitas kehidupan sosial masyarakat.

\section{KESIMPULAN}

Berdasarkan pemaparan dan uraian sebelumnya, maka dapat disimpulkan bahwa suatu keniscayaan bagi Ibnu Qayyim yaitu terjadinya transformasi dan perbedaan dalam hukum Islam, sehingga hukum Islam mampu beradaptasi dan terhadap perkembangan teknologi dan ilmu pengetahuan serta mampu merespon permasalahan-permasalahn kontemporer.

${ }^{21}$ Konsep ijtihad dalam terminologi ahli usul fikih adalah mengeluarkan segala potensi yang dimilikinya dalam hal ini seorang mujtahid untuk mengeksplorasi hukum-hukum syariat dengan cara penetapan hukum, Lihat Abd. Karim Zaedan, al-Wajiz fi Usul al-Fighi (Cet. II; Bairut: Muassasah al-Risalah, 1987), h. 401. Dan Muhammad Faraj Salim, Wafiz fi Usul al-Fighi (Cet. II; Kairo: al-Iman, 1965), h. 291. 


\section{Daftar Pustaka}

Abd. Karim, al-Wajiz fi Usul al-Fighi (Cet. II; Bairut: Muassasah al-Risalah, 1987.

Abdillah, Mujiono. Dialektika Hukum Islam dan Peubahan Sosial: Sebuah Refleksi Sosiologis Atas Pemikiran Ibn Qayyim al-Jauziyyah (Surakarta: Muhammadiyah University Press,. 2003.

Akkad, Abbas Mahmud.. al-Tafkir Faridah Islamiahi, (Kairo: Nahdah Masri, t.th.. al-Asmawi, Muhammah Said Jauhar al Islam .Cet. III; Kairo: Sina, 1993. Hasan, Abdillah F.. Tokoh-Tokoh Mashur Dunia Islam.Cet. I; Surabaya; Jawara,n 2004. al-Kahlani, Muhammad Ismail. Subul al-salam min Adillat al-Ahkam. Bairut: Dar- alFikr, 1979.

al-Jauziyah, Ibn Qayyim. I'lam al Muawaqqiin 'an al-Alamin, Juz III. Bairut: Dar alFikr, t.th.

al-Umri, Nadiyah Syarif. Ijtihad fi al-Islami: Usuluhu, aahkamuhu, afatuhu. Cet.I; Bairut; Muassasah al-Risalah, 2001.

Zaedan Muhammad Faraj Salim. Wafiz fi Usul al-Fighi. Cet. II; Kairo: al-Iman, 1965. 